\title{
Employment contracts after the reform of Lithuanian Labour Code
}

\section{Umowy o pracę po reformie litewskiego kodeksu pracy \\ dr Tatiana Wrocławska}

University of Lodz, Faculty of Law and Administration, Department of Labour Law

ORCID: 0000-0001-6780-8897

e-mail: twroclawska@wpia.uni.lodz.pl

dr Ingrida Macernyte-Panomarioviene

Mykolas Romeris University (Lithuania)

ORCID:0000-0003-0716-9354

e-mail: ingridam@mruni.lt

\begin{abstract}
Summary As the one of the main aim of the reform of Lithuanian labour law was indicated the need for providing more flexibility in employment relationships based on the Danish model of flexicurity, according to which the lower level of employment permanence is compensated by the system of effective benefits and facilities for employees in undertaking suitable work. This aim was accompanied by redefining of different instruments and legal regulations of individual labor law focused on fundamental changes related to employment protection and rights of dismissed employees, the types of employment contracts and working terms, as well as by introducing the new quality into collective labour relations. The changes introduced into Lithuanian labour law are along with the contemporary discussion on working standards in employment relationships and are demonstrating the new direction for development of Lithuanian labour law followed by Lithuanian legislator. Accordingly, the presented study is concentrated on legal analyses of the new types of employment contracts, which are aimed at providing more flexibility for parts of employment contracts accompanied by appropriate guarantees and security for employees.
\end{abstract}

Keywords: Lithuanian labour code, labour law reform, flexicurity, employment contracts, termination of employment contracts.

Streszczenie Jako jeden z głównych celów reformy litewskiego prawa pracy wskazywano potrzebę uelastycznienia stosunków zatrudnienia na wzór duńskiego modelu flexicurity, w ramach którego zmniejszenie gwarancji ochrony trwałości stosunków pracy pracowników jest rekompensowane efektywnym systemem świadczeń oraz łatwością pozyskiwania odpowiedniego zatrudnienia przez pracowników. Towarzyszyło temu przeredagowanie wielu instytucji i unormowań z zakresu indywidualnego prawa pracy, w tym zwłaszcza w zakresie trwałości zatrudnienia oraz uprawnień zwalnianych pracowników, rodzajów umów o pracę i warunków wykonywania pracy, a także wprowadzenie nowej jakości do regulacji zbiorowych stosunków pracy oraz uprawnień przedstawicieli pracowników. Zmiany dokonane $\mathrm{w}$ ramach reformy litewskiego prawa pracy wpisują się w dyskusję dotyczącą współczesnych standardów zatrudnienia pracowniczego oraz ukazują obrany przez ustawodawcę litewskiego nowy kierunek rozwoju prawa pracy: zdeterminowany postępem technologicznym i globalizacją oraz łączący większą elastyczność z systemem odpowiednich gwarancji pracowniczych. Autorki poddają analizie prawnej i ocenie unormowania określające nowe podstawy zatrudnienia pracowniczego.

Słowa kluczowe: litewski kodeks pracy, reforma prawa pracy, flexicurity, umowy o pracę, rozwiązywanie umów o pracę.

JEL: K31, J41, J81

Str. $12-20$

Bibliography 
PRACA I ZABEZPIECZENIE SPOŁECZNE NR 4/2019 • LABOUR AND SOCIAL SECURITY JOURNAL NO. 4/2019 ISSN 0032-6186 t. LX DOI 10.33226/0032-6186.2019.4.2

Davulis, T. (2017a). Lietuvos teise, 1918-2018 m.: šimtmeèio patirtis ir perspektyvos. Vilnius: Mykolo Romerio universitetas. 
Davulis, T. (2017b). Darbo teiseÿs rekodifikavimas Lietuvoje 2016-2017 m. Teiseÿ, (104).

Davulis, T. (2017c). Main Features of the Lithuanian Labour Law Reform 2016. In. T. Davulis, (ed.) Labour Law Reforms in Eastern and Western Europe. Brussels: Peter Lang.

Davulis, T. (2018). Lietuvos Respublikos darbo kodekso komentaras. Vilnius: VI Registru centras.

Macernyte-Panomarioviene, I. (2005). Darbo sutarties rušiu išskyrimas ir ju nustatymas, Jurisprudencija, 74(66), https://www3.mruni.eu/ojs/jurisprudence/article/view/2982/2783.

Macernyte-Panomarioviene, I. (2015). Legality of conclusion of fixed-term employment contract in Lithuania. Jurisprudencija, 22(1).

Maciulaitis, V. (2013). Darbo santykiu nutraukimas darbdavio iniciatyva nesant darbuotojo kaltes lankstumo ir saugumo aspektu. Daktaro disertacija: socialiniai mokslai (01S) teise, V.: MRU.

Modelis. (2015). Darbo santykiu Lietuvos socialinio modelio, apimanèio užimtumo didinima, darbo santykiu reglamentavimo tobulinima ir socialinio draudimo tvaruma, sukurimas, http://www.socmodelis.lt/wp- content/uploads/Modelis.pdf.

Zasciurinskas, M. (2016). LITEXIT. Nulines darbo sutartys - nuline gyvenimo kokybe, https://www.delfi.lt/news/ringas/politics/mzasciurinskas-litexit-nulines-darbo-sutartys-nuline-gyvenimo-kokybe.d?id=71854982. 